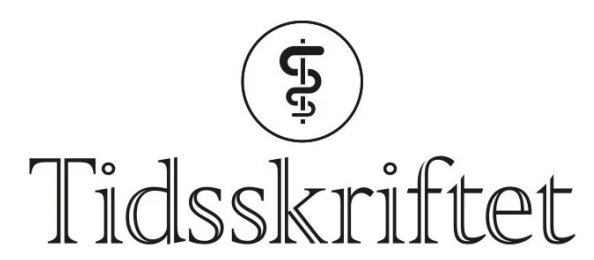

DEN NORSKE LEGEFORENING

\title{
Harald Kristian Heggenhougen
}

\author{
MINNEORD
}

BENTE MOEN

ASTRUD BLYSTAD

KAREN MARIE MOLAND

THORKILD TYLLESKÄR

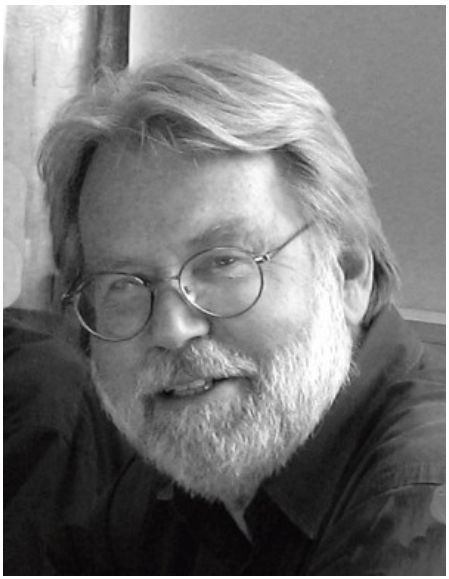

Foto: Thorkild Tylleskär

Det var med stor sorg vi mottok meldingen om Harald Kristian Heggenhougens død. Han ble 80 år gammel. Vi som var kolleger med ham, husker ham med stor glede. Vi minnes Kristian, antropologen med det store hjertet.

Kristian var engasjert i fattigdom, menneskerettigheter og helse. Han arbeidet ved Boston University School of Public Health (2001-09), Harvard Medical School og Harvard School of Public Health (1990-2000) og London School of Hygiene and Tropical Medicine (1979-90). Han hadde en stor vitenskapelig produksjon bak seg og var blant annet redaktør for International Encyclopedia of Public Health, et verk i seks bind.

Hans eget liv var en klassereise. Han ble født på Notodden i en velstående familie i 1940, men da foreldrene ble skilt i 1954, dro han med moren til Amerika der de levde et liv i trange kår. Etter collegeeksamen i 1962 dro han ut i verden: haiket tvers over USA, lærte spansk i Mexico og la ut på en lang reise i Latin-Amerika. En norsk båt ga ham skyss til Peru, 
så dro han til Chile, Argentina, Uruguay og Brasil. Rik på nye erfaringer og spørsmål kom han tilbake til USA i 1965 for å studere ved New School for Social Research, der han tok sin mastergrad i sosiologi. Så fulgte studier i antropologi og feltarbeid blant mayafolk i Guatemala, og den vitenskapelige karrieren var i gang. Kristian utførte senere lange etnografiske feltarbeid i Malaysia og Øst-Afrika. Møter med mennesker og samfunn på tre ulike kontinenter formet hans blikk på global helse og ulikhet.

Kristian arbeidet på Senter for internasjonal helse i perioden 2000-15, og han var av uvurderlig betydning. Han var en forsker som beveget seg i faggrensene, alltid interessert i kunnskapen og synspunktene til dem han møtte. Han var elsket av studenter så vel som kolleger. Han var en formidler av de sjeldne, underviste med humor og innlevelse, med tyngde og faglig autoritet, alltid med et perspektiv på fattigdom og sosial rettferdighet. Han var et fantastisk varmt menneske som var mer opptatt av andres styrke enn sin egen.

De siste årene av livet var Kristian syk, og døde hos sin datter i California 12. august i år. Han er dypt savnet hos oss. Vi sender våre tanker til Nina, Anne Marie og familien.

Kolleger ved Senter for internasjonal helse ved Universitetet $i$ Bergen

Publisert: 28. september 2020. Tidsskr Nor Legeforen. DOI: 10.4045/tidsskr.20.0677

(C) Tidsskrift for Den norske legeforening 2023. Lastet ned fra tidsskriftet.no 26. april 2023. 